\title{
A study of Epstein-Barr virus infection in the Chinese tree shrew(Tupaia belangeri chinensis)
}

\author{
Zhi Wang ${ }^{1}$, Xiang Yi ${ }^{1}$, Long Du ${ }^{1}$, Hong Wang ${ }^{1}$, Jie Tang ${ }^{1}$, Menglin Wang ${ }^{1}$, Chenglin Qi ${ }^{1}$, Heng Li ${ }^{1}$, Yongjing Lai ${ }^{1}$,
} Wei Xia ${ }^{1}$ and Anzhou Tang ${ }^{1,2^{*}}$

\begin{abstract}
Background: Epstein-Barr virus (EBV) is closely associated with many human diseases, including a variety of deadly human malignant tumours. However, due to the lack of ideal animal models,the biological characteristics of EBV, particularly its function in tumourigenesis, have not been determined. Chinese tree shrews (Tupaia belangeri chinensis), which are similar to primates, have been used to establish a variety of animal models and have recently received much attention. Here, we established tree shrews as a model for EBV infection by intravenous injection.

Methods: Ten tree shrews were inoculated with EBV by intravenous injection,and blood was collected at regular intervals thereafter from the femoral artery or vein to detect EBV markers.

Results: Eight of 10 tree shrews showed evidence of EBV infection. In the 8 EBV-infected tree shrews, EBV copy number increased intermittently or transiently, EBV-related gene expression was detected, and anti-EBV antibodies increased to varying degrees. Macroscopic hepatomegaly was observed in 1 tree shrew, splenomegaly was observed in 4 tree shrews, and enlarged mesenteric lymph nodes were observed in 3 tree shrews. Haematoxylin and eosin (HE) staining showed splenic corpuscle hyperplasia in the spleens of 4 tree shrews and inflammatory cell infiltration of the liver of 1 tree shrew and of the mesenteric lymph nodes of 3 tree shrews. EBER in situ hybridization(ISH) and immunohistochemical (IHC) staining showed that EBER-, LMP1- and EBNA2- positive cells were present in the spleens and mesenteric lymph nodes of some tree shrews. Western blotting (WB) revealed EBNA1-positive cells in the spleens of 4 tree shrews. EBV markers were not detected by HE, EBER-ISH or IHC in the lung or nasopharynx.
\end{abstract}

Conclusions: These findings suggest that EBV can infect tree shrews via intravenous injection. The presented model offers some advantages for exploring the pathophysiology of EBV infection in humans.

Keywords: Epstein-Barr virus, Tree shrews, Animal model, Infection

\section{Background}

Epstein-Barr virus (EBV) was first isolated from Burkitt lymphoma cells in 1964. The virus targets B lymphocytes and belongs to the human herpesvirus 4 family. The virus is wide spread,and more than $90 \%$ of adults are infected and are carriers for life [1]. EBV is spread through saliva and can also be transmitted through blood or

\footnotetext{
* Correspondence: anzhoutang@163.com

${ }^{1}$ Department of Otorhinolaryngology Head and Neck Surgery, The First Affiliated Hospital of Guangxi Medical University, Nanning, Guangxi, China ${ }^{2}$ Key Laboratory of Early Prevention and Treatment for Regional High Frequency Tumor, Ministry of Education, Nanning, Guangxi, China
}

sexual contact [2]. Its growth cycle includes two forms: a lytic period and a latent period. The lytic period, which is the proliferation period of EBV, consists of three consecutive phases with immediate early (IE)-, early (E)- and late $(\mathrm{L})$-expressing genes. The IE genes includeBZLF1(Zta)and BRLF1(Rta),the first transcription factors to appear during the lytic stage switch. The viral DNA is completely replicated for assembly during this period [3]. The latent period is the non-proliferative stage of EBV and is divided into three states according to the different latent genes that are expressed. Primary EBV infection passes through all three latent states before final co-existence with the 
host for long-term stability. When EBV infects restingstate B cells, it often establishes latency III and expresses all latent genes, including 3 latent membrane protein genes (LMPs), 6 nuclear antigen genes, and 2 nonprotein-encoding RNAs (EBERs, EBER-1and EBER-2) [4]. The infected $B$ cells then differentiate into memory B cells and proliferate. When the memory B cells that carry EBV enter the germinal centre B cells (centroblasts and centrocytes), latency II emerges with limited latent gene expression (LMPs, EBNA1, BARTs and EBERs). Latency I, which involves EBNA1 and EBERs expression,has been detected in proliferating memory $B$ cells, and latency 0 , without EBV protein expression but with the presence of nontranslated viral RNAs, was demonstrated in resting memory B cells [5]. In vitro, EBV can specifically transform human peripheral blood B cells to EBV-infected latency III immortalized cell lines (lymphoblastoid cell lines, LCLs [6], and latent EBV proteins directly or indirectly play a key role in promoting the proliferation and transformation of the infected cells during this process [7-11].

Compared with infection in vitro, the mechanism of EBV infection in vivo is more complex and poorly understood. EBV is a tumourigenic virus, and the various latent infection states are also associated with different diseases, such as post-transplantation lymphoid cell hyperplastic diseases (post-transplantation lymphoproliferative disorders, PTLD) caused by the proliferation of infected cells and primarily due to EBV latency III infection, Hodgkin's disease and nasopharyngeal carcinoma due to EBV latency II infection,and Burkitt lymphoma due to latency I infection. EBV is also associated with infectious mononucleosis, EBV-associated haemophagocytic syndrome and gastric carcinoma [12]. However, due to the lack of ideal animal models, the biological characteristics of EBV, particularly its function in tumourigenesis, have not been determined. Therefore, it is necessary to establish a suitable experimental EBV animal model.

Since the discovery of EBV, animal models of EBV infection have been established in various species, including primates, severe combined immune-deficiency (SCID) mice, transgenic animals, rabbits and guinea pigs. A variety of lymphomas have been induced using EBV continuous infection in cotton-top marmoset animal models [13-15]. B lymphocyte tissue hyperplasia and lymphoma have been observed in EBV animal models based on human peripheral blood lymphocytes (huPBLs)and the SCID mouse (hu-PBL-SCID mice) [16-19]. Studies of EBV using transgenic animal models have focused on individual genes such as EBNA1 and LMP1 [20-22]. Recent studies have confirmed that rabbits can be infected with EBV via venous and nasal inoculation [23-25] and that EBV can infect rabbit B cells in vitro [26]. Although these animal models have played important roles in studying the EBV infection process, its pathogenic mechanism, and its prevention and treatment, they also present some disadvantages. For human diseases, animal models of EBV infection involving non-human primates have irreplaceable advantages. Therefore, an EBV animal model that resembles human disease is urgently needed for the study of the biological characteristics of EBV and its associated diseases.

In this study, tree shrews (Tupaia belangeri chinensis) were used to establish an animal model of natural EBV infection. Tree shrews aresmall animals that are closely related to primates and live in tropical and subtropical regions; theirlife span is approximately eight years, and they are easily bred [27].Tree shrews are mainly distributed in Yunnan and Guangxi provincesin China and have been increasingly used in scientific and biomedical research in recent years. The Kunming Institute of Zoology recently analysed the entire genome, transcriptome [28] and proteome [29] of tree shrews. The results confirmed that tree shrews are closely genetically related to primates and that they have a high degree of similarity to primates and humans in physiological anatomy, neural development, and psychological stress responses. Many of the characteristics of viral infection in tree shrews are also similar to those of humans, and tree shrews can be infected by hepatitis A virus (HAV), hepatitis $\mathrm{B}$ virus $(\mathrm{HBV})$, hepatitis $\mathrm{C}$ virus $(\mathrm{HCV})$, rotavirus (HRV), adenovirus (ADV), and herpes virus (HSV) [30-35]. In addition, tree shrews have been used to establish animal models of drug-resistant bacterial infection and sepsis, psychological stress and depression, myopia, and metabolic disease [36-38]. Therefore, we studied whether tree shrews can be developed into a new type of animal model that is closer to primates than other existing animal models. Studies have shown that EBV hosts are limited to humans and New World monkeys, including the cotton-top marmoset, the common marmoset and the owl monkey [39] and that the infected cells are B lymphocytes and epithelial cells. Based on previous research and on the high similarity of tree shrews to primates, we proposed that tree shrews will be susceptible to Epstein-Barr virus infection and that they possess good potential for use as an animal model of EBV infection in humans.

\section{Results}

\section{Effects of EBV inoculation in tree shrews}

The effects of EBV inoculation in tree shrews are presented in Table 1. Thirteen tree shrews were used in this study, including 10 inoculated with $500 \mu \mathrm{l}$ of EBV by intravenous injection and 3 inoculated with RPMI 1640 culture medium containing 10\% foetal bovine serum using a similar procedure. Blood was collected prior to inoculation and every 1 or 2 weeks 
Table 1 Summary of EBV infection in tree shrews

\begin{tabular}{|c|c|c|c|c|c|c|c|c|}
\hline Tree shrew Number & EBV copies & EBV mRNA & EBV antibodies & EBERs & HE & $\mathrm{IHC}$ & WB & Observation period \\
\hline Ts 1 & + & + & $+V C A \lg G$ & - & - & - & - & 4 weeks(dead) ${ }^{a}$ \\
\hline Ts 2 & + & + & $+V C A \lg G$ & + & + & - & + & 6 weeks(dead) ${ }^{a}$ \\
\hline Ts 3 & + & + & $+V C A \lg G$ & + & + & - & + & 12 weeks(euthanasia) \\
\hline Ts 4 & + & + & $+V C A \lg G$ & - & - & - & - & 5 weeks(euthanasia) \\
\hline Ts 5 & - & - & - & - & - & - & - & 21 weeks(euthanasia) \\
\hline Ts 6 & - & - & - & - & - & - & - & 3 weeks(euthanasia) \\
\hline Ts 7 & + & + & $+($ VCA lgG、 EBNA lgG) & + & + & + & - & 21 weeks(euthanasia) \\
\hline Ts 8 & + & + & $+V C A \lg G$ & - & - & - & - & 6 weeks (dead) ${ }^{a}$ \\
\hline Ts 9 & + & + & $+V C A \lg G$ & - & - & - & + & 21 weeks(euthanasia) \\
\hline Ts 10 & + & + & $+V C A \lg G$ & + & + & + & + & 3 weeks(euthanasia) \\
\hline \multicolumn{9}{|l|}{ Negative control } \\
\hline Ts 11 & - & - & - & - & - & - & - & 13 weeks(euthanasia) \\
\hline Ts 12 & - & - & - & - & - & - & - & 5 weeks(euthanasia) \\
\hline Ts 13 & - & - & - & - & - & - & - & 5 weeks(euthanasia) \\
\hline
\end{tabular}

+ , positive; -, negative

${ }^{a}$ The 3 tree shrews that died prior to the end of the experiment may have died from infectious disease but the cause of death was undetermined

after inoculation. The number of copies of the EBV detected increased intermittently or transiently in the PBMCs of eight of the 10 tree shrews, and EBVrelated antibodies increased by varying degrees. Animals Ts3 and Ts4 displayed severe weakness and were euthanized at week 12 and week 5. Another three of the 13 tree shrews (Ts1,2 and 8) died prior to the end of the experiment, but there was no evidence that the deaths resulted from EBV infection. The remaining 8 animals appeared to be normal and displayed no weakness after EBV inoculation. They were euthanized at times ranging from 3 to 21 weeks after inoculation with the virus, and their tissues were assayed for pathological changes.

EBV copy number in PBMCs of tree shrews post-infection

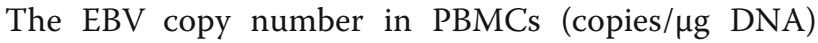
was determined using qPCR. The results are shown in Fig. 1. Eight of the 10 tree shrews showed evidence of EBV infection. In 3 of the tree shrews, EBV copy number increased intermittently and appeared to fluctuate (Fig. 1a). However, in the other 5 tree shrews, EBV copy number increased to the highest value at week 2 or 4 and followed by a decline, as shown in Fig. 1b. Among the 8 infected tree shrews, the copy number of EBV was highest in Ts9 (12,233 copies/ $\mu \mathrm{g}$ DNA); this represented a transient increase in the EBV copy number. The data for Ts5 and Ts6 are shown as representative of EBV-infected-negative tree shrews (Fig. 1c). In Ts5, Ts6 andTs11-Ts13, the EBV copy number did not increase during the observation period (data not shown).

\section{Expression of EBV genes in PBMCs of tree shrews post-} infection

RT-PCR analysis of BZLF1, EA, EBNA1, EBNA2, and LMP1 was performed; the results are summarized in Figs. 2, 3 and 4.In Ts1 and Ts2, only EBNA1 and LMP1 were detected at week 4 , respectively. In Ts3, BZLF1 was expressed from weeks 6 to 10, and LMP1 was observed only at week 6 .In Ts4, BZLF1 was expressed from weeks 2 to 4 , and the expression of LMP1 persisted throughout the observation period with the exception of week 4(Fig. 2). In Ts7, the expression of LMP1 persisted throughout the observation period, excluding week 2, BZLF1 appeared at weeks 2 to 4,EA was detected intermittently from weeks 4 to 18 , and EBNA1 was observed only at week 18. In Ts8, EBNA1, EBNA2 and LMP1were expressed at week 2 . In Ts9, LMP1was detected at weeks 2, 6 and 21, and EA and EBNA1were detected only at weeks 2 and 16, respectively. In Ts10, the expression of BZLF1 persisted throughout the observation period,and LMP1 was detected at week 1 (Fig. 3). None of these genes were detected in Ts5, Ts6 or in the 3 tree shrews (data not shown) that were injected with RPMI 1640 culture medium containing $10 \% \mathrm{FBS}$ as a negative control. $\beta$-actin was used as an internal control, and the cDNA of B95-8 cells was used as a positive control (Fig. 4).

\section{Levels of EBV antibody in the serum of tree shrews post- infection}

EBV antibodies in tree shrew serum were measured by ELISA. The results are shown in Fig. 5. The level of VCA IgG increased to varying degrees in all tree shrews in which the EBV copy number increased, but EBNA1 


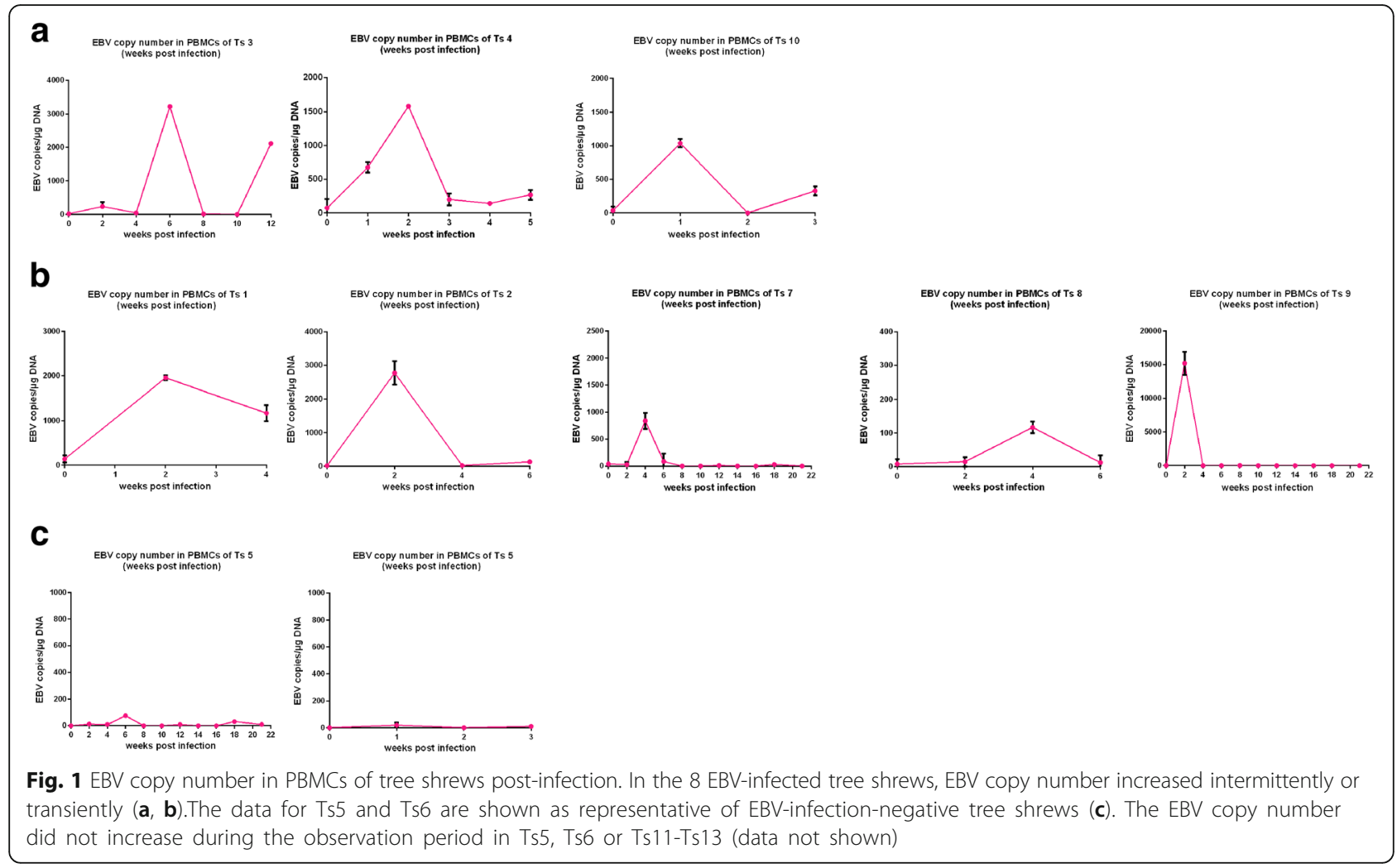

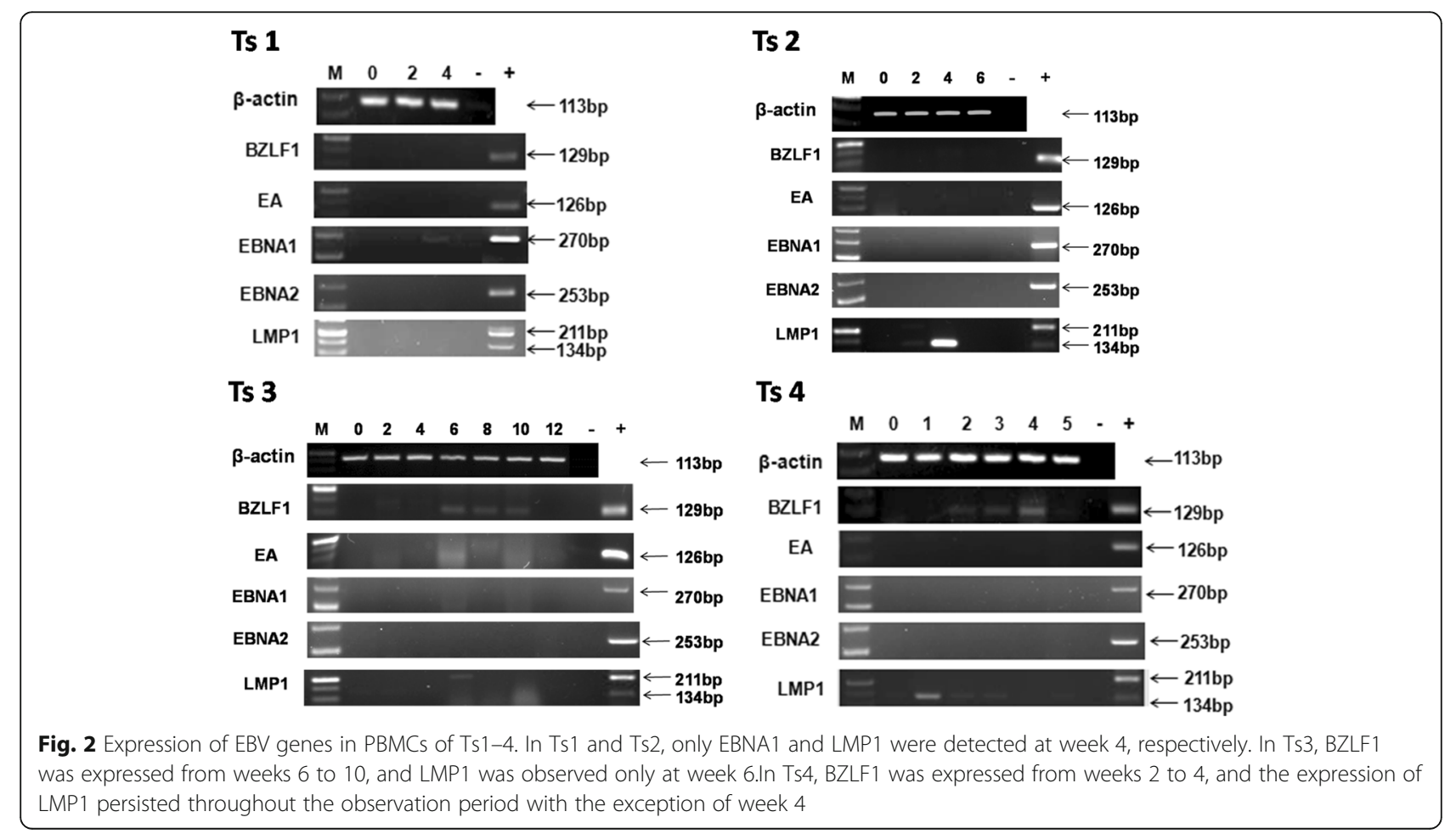




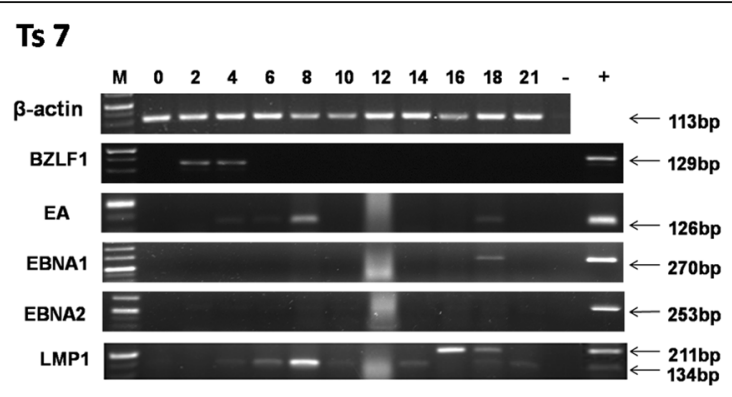

Ts 9

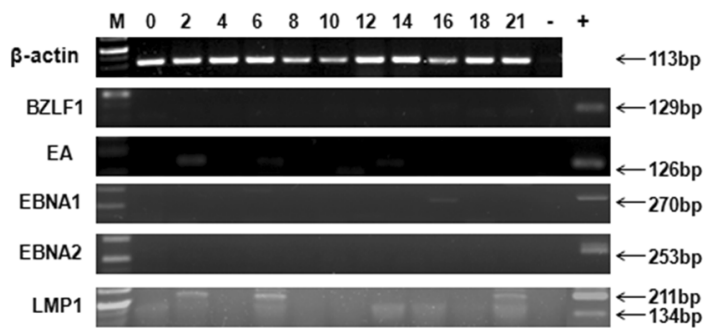

Ts 8

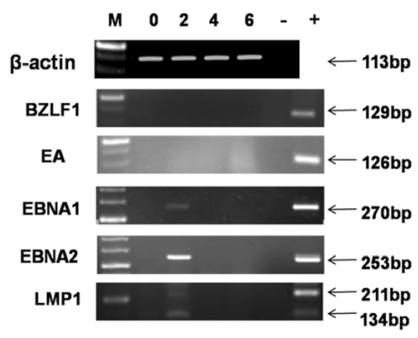

Ts 10

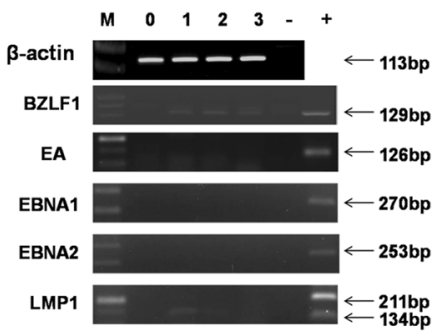

Fig. 3 Expression of EBV genes in PBMCs of Ts7-10. In Ts7, the expression of LMP1 persisted throughout the observation period, excluding week 2, BZLF1 appeared at weeks 2 to 4,EA was detected intermittently from weeks 4 to 18, and EBNA1 was observed only at week 18. In Ts8, EBNA1, EBNA2 and LMP1 were expressed at week 2. In Ts9, LMP1was detected at weeks 2, 6 and 21, and EA and EBNA1were detected only at weeks 2 and 16, respectively. In Ts10, the expression of BZLF1 persisted throughout the observation period,and LMP1 was detected at week 1

IgG increased only in 1 tree shrew (Ts7), and EA IgG was not elevated, as shown in Fig. 5a. The levels of these antibodies were not increased in the EBV-infectionnegative tree shrews (Fig. 5b) or in any of the 3 tree shrews that served as negative controls (data not shown).

\section{Haematoxylin and eosin (HE) analysis of tree shrew tissues}

HE staining showed that compared with the negative controls, splenic corpuscle hyperplasia was detected in the spleens of four (Ts2,3,7 and 10)of the 8 infected tree shrews and was most obvious inTs7 (Fig. 6).In the liver, extensive inflammatory cell infiltration was detected in only 1 (Ts2) of the 8 infected tree shrews (Fig. 7a).Extensive lymphocyte proliferation was observed in 3 animals (Ts3,7 and 10) with mesenteric lymph node enlargement (Fig. 7b). Ts11 served as the negative control. No obvious abnormalities in the lung or nasopharynx were detected after HE staining (data not shown).

\section{Detection of EBV in tree shrew tissues}

EBER-ISH was performed on 5- $\mu \mathrm{m}$ sections of formalinfixed, paraffin-embedded tissue sections of the spleen, liver, mesenteric lymph nodes, lung and nasopharyngeal tissues of autopsied tree shrews. EBER-positive cells were detected in the spleen and mesenteric lymph nodes of 3 different tree shrews (Figs. 8 and 10a).EBERs were expressed in the nucleus. B95-8 cells and Ts11 were used as positive and negative controls, respectively. Ts6 was an EBV-infection-negative tree shrew. No EBERpositive cells were detected inTs6 or Ts11.

\section{Ts 5}

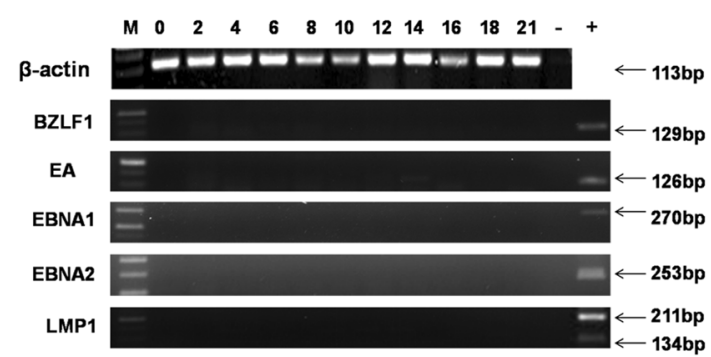

Ts 6

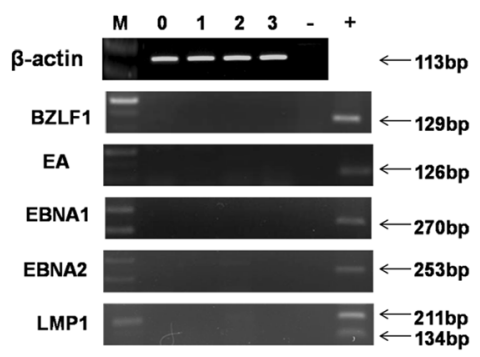

Fig. 4 Expression of EBV genes in PBMCs of Ts5 and Ts6. No EBV gene expression was detected in Ts5 or Ts6 or in the 3 tree shrews that were used as negative controls (data not shown) 


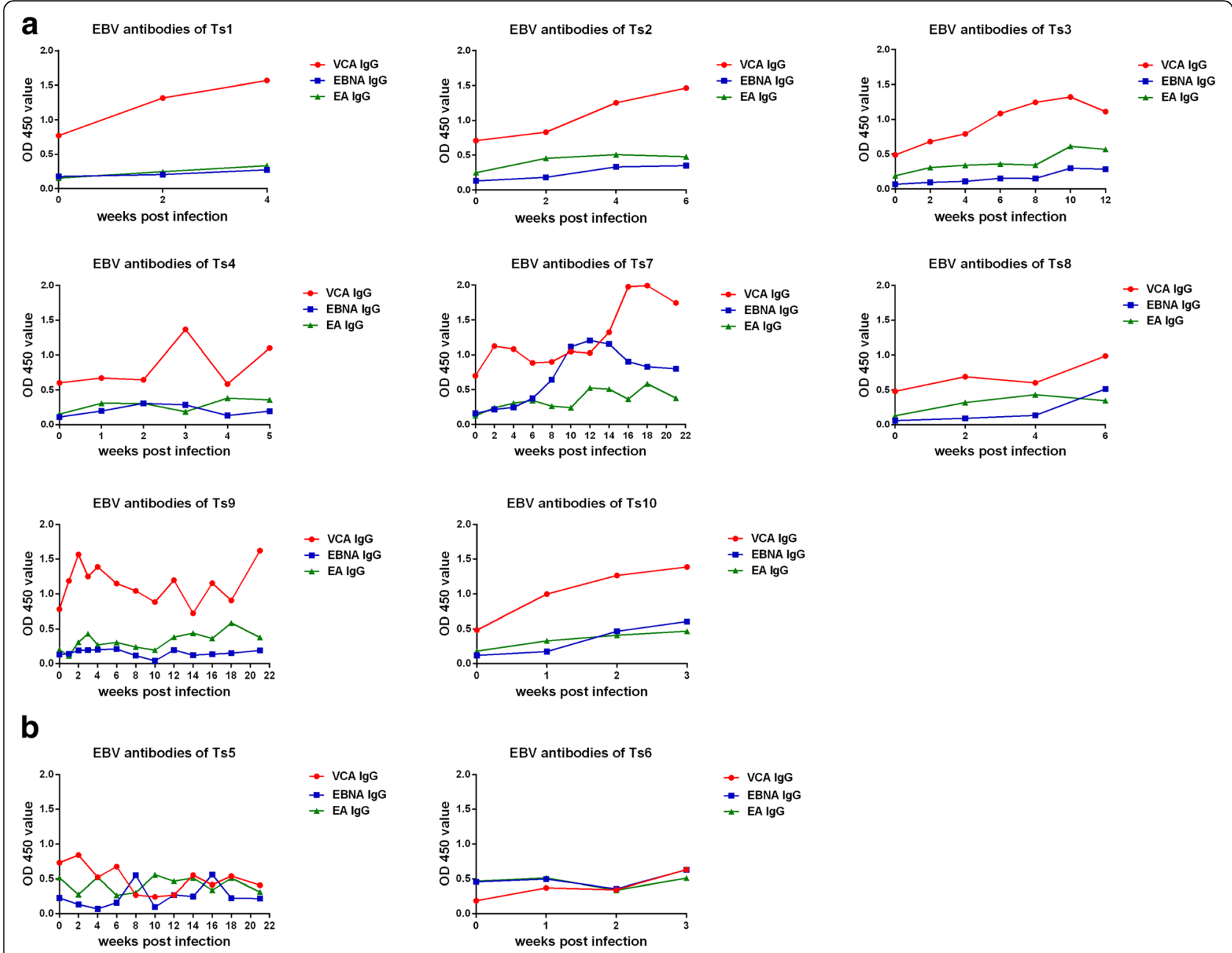

Fig. 5 Levels of EBV antibody in the serum of tree shrews post-infection. The level of VCA IgG increased to varying degrees in all tree shrews in which the EBV copy number increased; EBNA1 lgG increased in only1 tree shrew (Ts7),and EA IgG was not elevated (a). The levels of these antibodies were not increased in the EBV-infection-negative tree shrews (b) or in any of the 3 tree shrews that served as negative controls (data not shown)

\section{Immunohistochemical detection of EBV gene expression} The spleens, livers, mesenteric lymph nodes, lungs and nasopharyngeal tissues of the tree shrews were examined for LMP1 and EBNA2 expression using immunohistochemistry.LMP1- and EBNA2-positive cells were detected in the spleen of Ts10 only by immunohistochemistry. These positive cells were limited to the germinal centre (Fig. 9). In Ts7 only, LMP1 expression was detected in the mesenteric lymph nodes by immunohistochemistry (Fig. 10b). No EBNA2 expression was detected in the mesenteric lymph nodes of the three tree shrews with mesenteric lymph node enlargement (data not shown). LMP1 was expressed in the cytomembrane and cytoplasm, whereas EBNA2 was expressed in the nucleus. B95-8 cells and Ts11 were the positive and negative controls, respectively. Ts6 was an EBVinfection-negative tree shrew. No LMP1or EBNA2 expression was detected in Ts6 or Ts11.

\section{Western blotting for the detection of EBV gene expression}

We performed Western blotting to detect the expression of EBNA1 in the livers and spleens of the tree shrews. As shown in Fig. 11, EBNA1 expression was detected in the spleens of Ts2, Ts3, Ts9 and Ts10, but no EBNA1 expression was detected in the livers of any of the animals. B95-8 cells and Ts11-13 were used a spositive and negative controls, respectively. Ts5 and Ts6 were EBVinfection-negative. No EBNA1expression was detected inTs5, Ts6 or Ts11-13.

\section{Discussion}

In this study, we inoculated10 tree shrews with EBV via intravenous infusion. Only eight tree shrews were successfully infected, albeit to different extents. The determination of EBV copy number in the PBMCs of tree shrews revealed that the infection observed in this study 


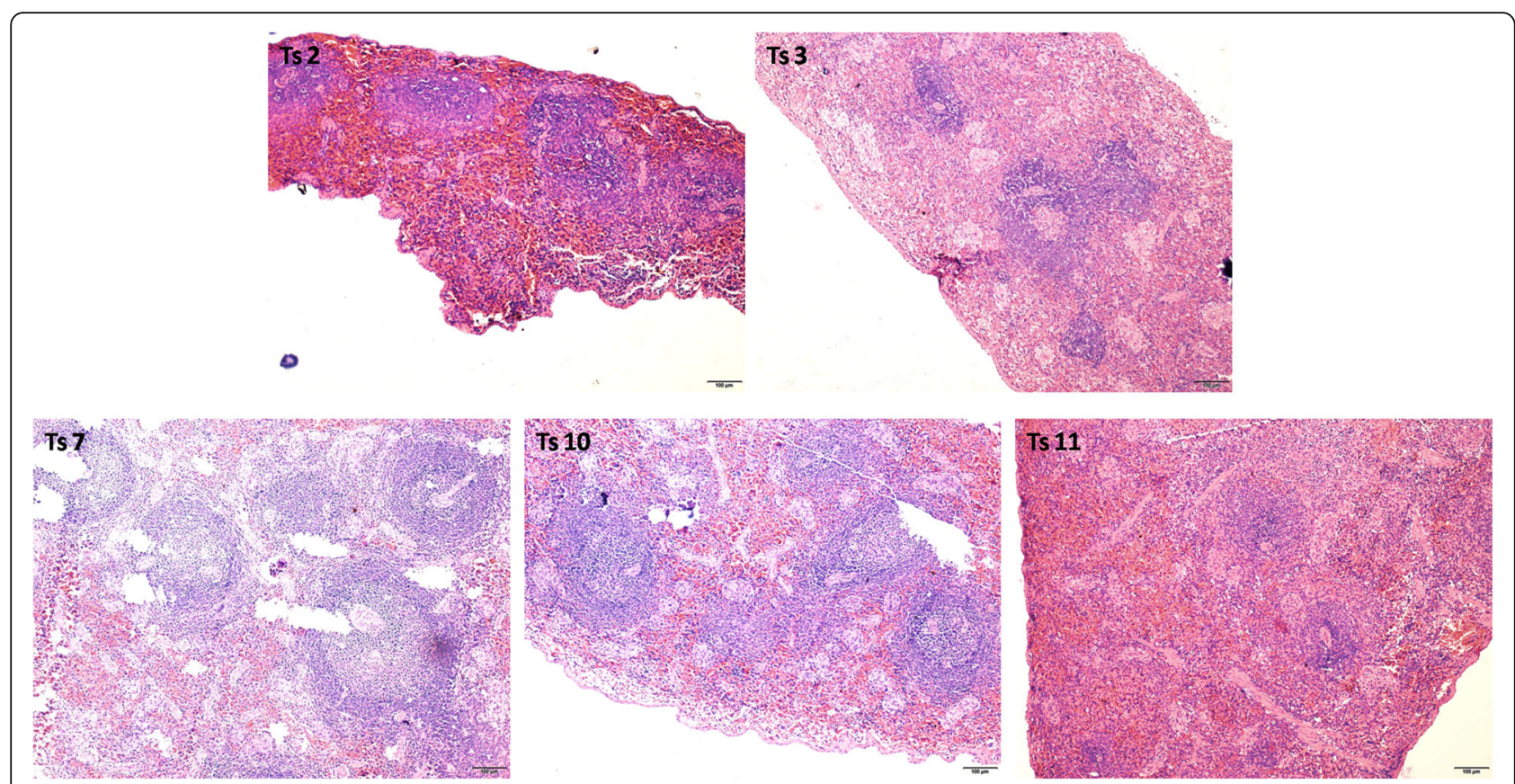

Fig. $6 \mathrm{HE}$ staining of the spleens of tree shrews. Splenic corpuscle hyperplasia was detected in the spleens of four (Ts2,3,7,10)of the 8 infected tree shrews and was most obvious inTs7.Ts11 is the negative control

can be divided into three types: EBV infection-negative (Ts5 and 6);infection in which EBV copy number intermittently increased (Ts3,4 and 10); and infection in which EBV copy number transiently increased (Ts1,2,7,8 and 9). The differences in EBV copy number observed in the tree shrews in this study may be due to the different virus removal abilities of the tree shrews. In humans, infection with EBV stimulates $\mathrm{CD} 23^{+} \mathrm{B}$ lymphocyte proliferation. The proliferated B cells replicate the virus [40] and stimulate $\mathrm{CD} 4^{+} \mathrm{T}$ cell proliferation. During the stage of viral replication, $\mathrm{CD} 4^{+} \mathrm{T}$ cells release lymphatic factors that modify the local inflammatory response and limit the proliferation of infected $\mathrm{B}$ cells, and $\mathrm{CD} 4^{+} \mathrm{T}$ cells are greatly depleted [41]. Under conditions of intense viral antigen stimulation, $\mathrm{CD}^{+} \mathrm{T}$ cells proliferate. The activity of $\mathrm{CD}^{+} \mathrm{T}$ cells can also be greatly enhanced and can have a very strong cytotoxic effect.CD $8^{+} \mathrm{T}$ cells attack and destroy virus-infected $\mathrm{CD} 23^{+} \mathrm{B}$ cells in body fluids and lymph nodes, inhibit their abnormal proliferation, release excessive cytokines and simultaneously cause

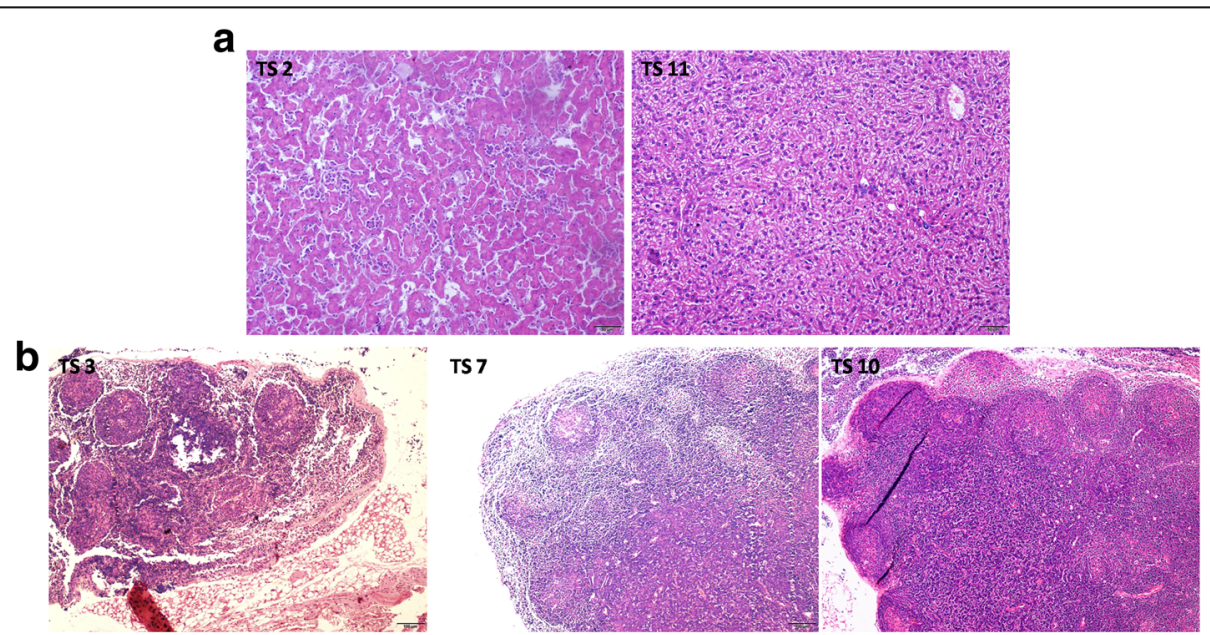

Fig. $7 \mathrm{HE}$ staining of the livers and mesenteric lymph nodes of tree shrews. Extensive inflammatory cell infiltration in the liver was detected in only 1(Ts2) of the 8 infected tree shrews (a). A large amount of lymphocyte proliferation was detected in 3 animals (Ts3,7 and 10) with mesenteric lymph node enlargement (b). Ts11 is the negative control 

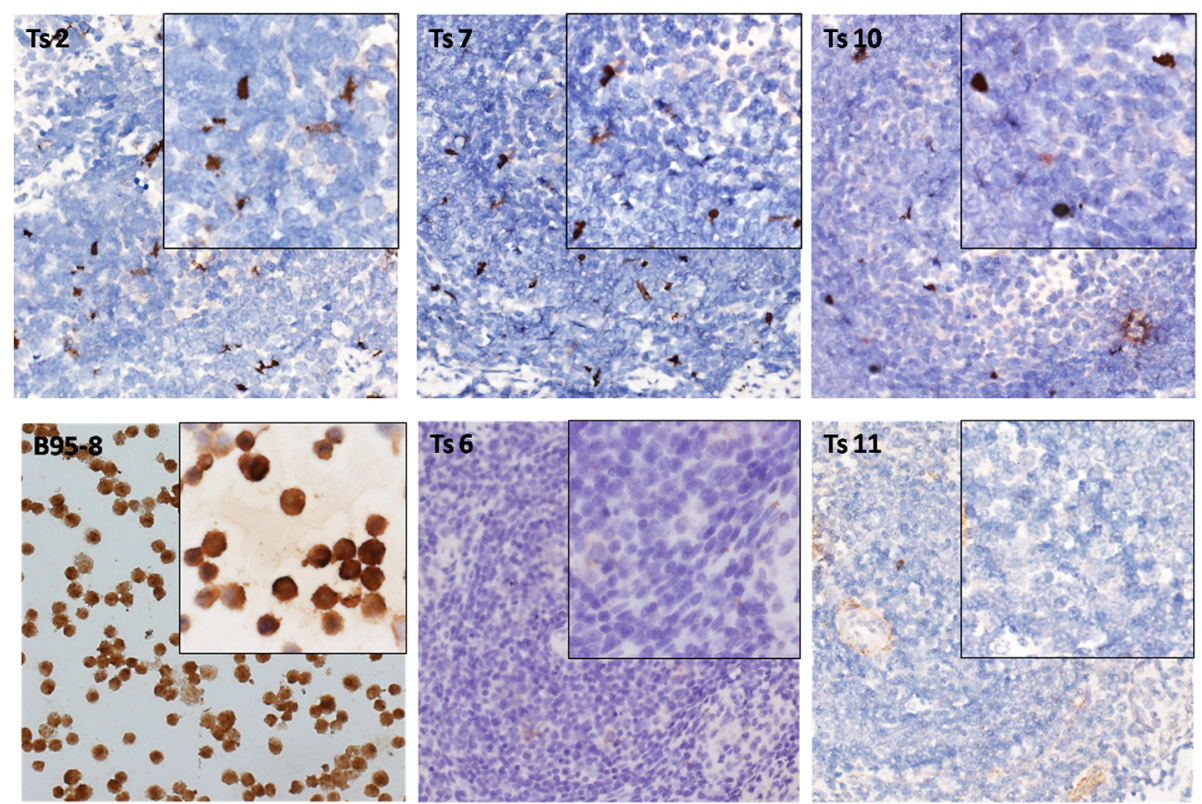

Fig. 8 EBER-ISH staining of the spleens of tree shrews. EBER-positive cells were detected in the spleens of three of the ten tree shrews.B95-8 cells and Ts11 were used as positive and negative controls,respectively. Ts6 was an EBV-infection-negative tree shrew. No EBER-positive cells were detected inTs6 or Ts 11

symptoms of infectious mononucleosis (IM) [42], an EBV-associated disease. When the body's immune system is functioning normally, most EBV copies are removed, and this may explain why the EBV copy numbers initially increased in some tree shrews but then decreased. However, EBV can occasionally escape the body's immune surveillance through an unknown mechanism and attack the cells, resulting in a failure of the immune system to recognize and destroy virus-infected $\mathrm{CD} 23^{+} \mathrm{B}$ cells. EBV can be present in latent form longterm in B lymphocytes or be reactivated when immune system function declines, resulting in a fluctuation in EBV copy number in the human body. Similar phenomena may have been responsible for the continuous increase in EBV copy number in some of the tree shrews in this study.

Using RT-PCR, we detected EBV-related gene expression after infection, including expression of the pyrolysis-related protein EBV BZLF1(Zta) and expression of the early gene (EA), both of which appear during the hyperplastic cracking stage of infection,as well as of related genes such as LMP1, EBNA1 and EBNA2 that

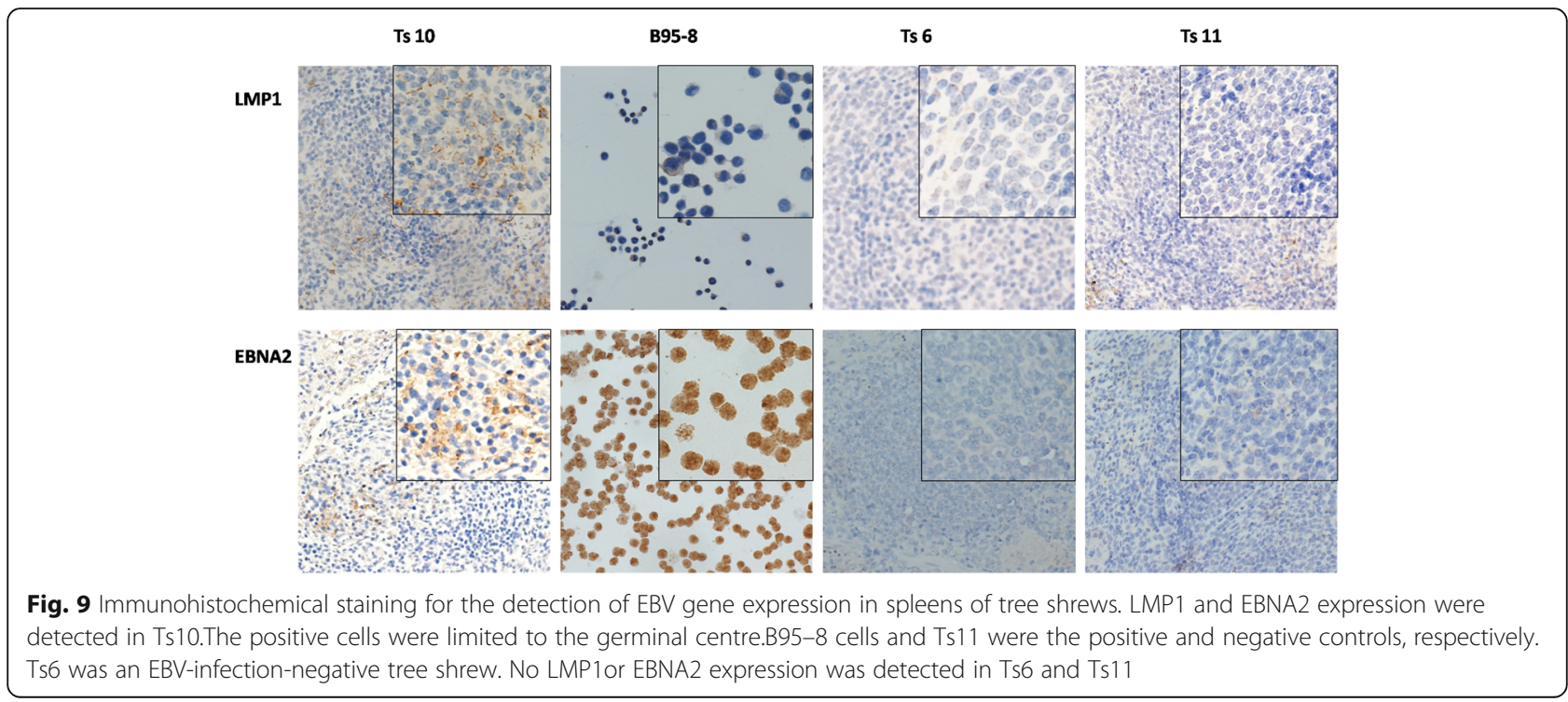



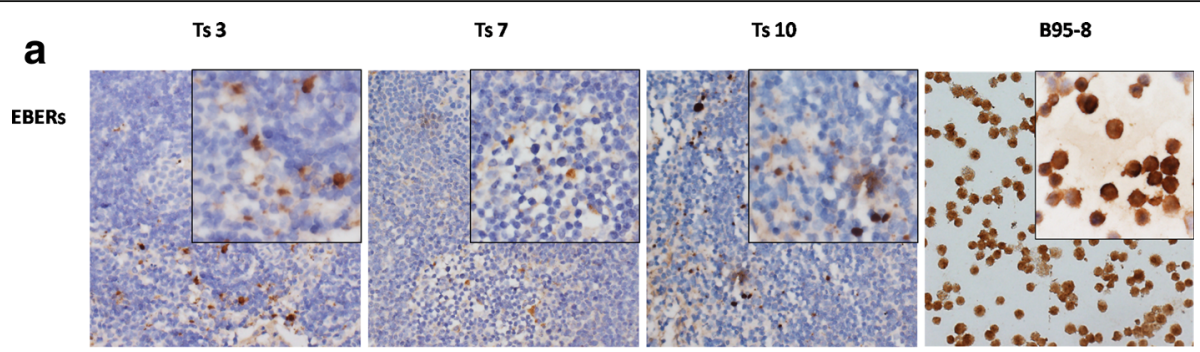

b
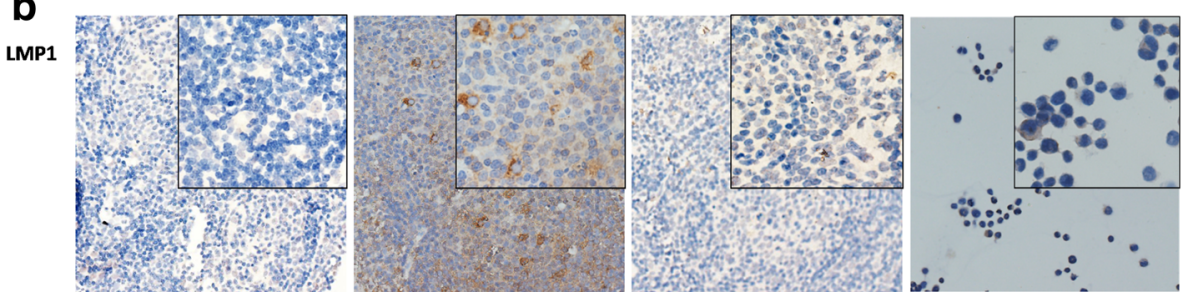

Fig. 10 EBER-ISH and immunohistochemical staining of EBV gene expression in mesenteric lymph nodes of tree shrews. EBER-positive cells were detected in the mesenteric lymph nodes of three of the 10 tree shrews (a).LMP1 expression was detected in the mesenteric lymph nodes by immunohistochemistry only in Ts7 (b). No EBNA2 expression was detected in the mesenteric lymph nodes of the three tree shrews with mesenteric lymph node enlargement (data not shown)

appear in the latent infection stage. BZLF1 is a transcription factor of the cracking stage switch, and its expression occurs in the absence of the synthesis of any other viral proteins. BZLF1 may participate in the regulation of the cell cycle and cell proliferation [43], prompted by a change in viral infection from latent infection to lytic infection [19]. EA mainly appears during the acute phase of infection and is involved in viral DNA replication and blocking antigen presentation,among other roles [44]. Among the genes expressed after EBV expression, LMP1 is an important cancer-related gene and plays an important role in $\mathrm{B}$ cell and epithelial cell transformation, proliferation, and apoptosis [45]. In all 8 EBV-infectionpositive tree shrews, BZLF1 and LMP1 were the easiest viral proteins to detect, and their expression was most typical in Ts3, Ts4, Ts7, and Ts10. The expression of EA and EBNA1 was detected occasionally in Ts7. In Ts7, for example, the EBV lytic protein gene BZLF1 was expressed at the beginning of infection, leading to viral replication, EA expression and an increase in the EBV copy number. However, later during infection, the body's interventions, such as immune defences, result in a decrease in EBV copy number, expression absent of BZLF1. As the infection enters the latent phase, EBNA1 expression appears. This result is consistent with the histopathological results showing that EBER-positive and LMP1-positive cells were present in the spleen and the mesentericlymph nodes, findings that are compatible with the presence of latency II, III and lytic infection. Furthermore, different cells may have been in different latent phases. LMP1 was detected during the entire observation period in Ts7, suggesting that Ts7 was in a state of long-term latent infection. For Ts9,expression of EA and LMP1 appeared at week 2, a finding that is coincidental with the observation of maximal viral copy number inTs9 at week 2. Expression of EBNA1 appeared at week16 when no related genes had been expressed for several weeks, indicating that the infection had entered a latent stage resembling latency II infection. Although EBNA1 and EBNA2 are also important genes during EBV latent infection development [46], their expression was detected only occasionally in the 8 tree shrews. The most typical results were observed in Ts1 and Ts8. All gene detection was performed using $\mathrm{B} 95-8$ as a positive

\section{EBNA1}

Ts 1 Ts 2 Ts 3 Ts 4 Ts 5 Ts 6 Ts7 Ts 8 Ts 9 Ts 10 Ts 11 Ts 12 Ts 13 B95-8

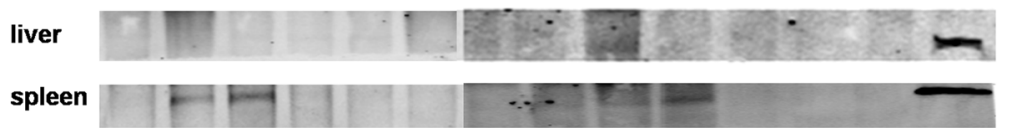

Fig. 11 Western blotting for the detection of EBV gene expression in the livers and spleens. EBNA1 was detected in the spleens of Ts2, Ts3, Ts9 and Ts10. No EBNA1 expression was detected in the livers of any of the tree shrews. B95-8 cells and Ts11-13 were used as positive and negative controls, respectively. Ts5 and Ts6 were EBV-infection-negative. No EBNA1expression was detected inTs5, Ts6 or Ts11-13 
control and without template as a negative control.LMP was detected in the positive control and all samples as products of two sizes, $134 \mathrm{~kb}$ and/or $211 \mathrm{~kb}$. By searching the NCBI gene bank, we confirmed that polypeptides of these two sizes can indeed be amplified by the same primers and that both are EBV-related gene products.

VCA IgG antibodies, which increase continuously from the acute phase of EBV infection in humans [47], were elevated to varying degrees after EBV vaccination in this experiment, similar to the previously reported changes in VCA IgG levels in the human body after EBV infection. Although EA IgG mainly appears during the acute infection period or during the reactivation phase [44], it was not elevated in any of the tree shrews in this study during an observation period of up to 21 weeks. EBNA IgG, which appears during the recovery period of EBV infection and persists at high levels [48], was not elevated in any of the tree shrews except Ts7. These observations suggest that the immune response of the tree shrew to EBV is different from that of humans. It is currently difficult to determine the exact reason for this difference. Therefore, it appears to be vitally important to determine the function of antibodies against VCA,EBNA and $\mathrm{EA}$ in tree shrews in vivo.

We did not detect VCA IgM, which in humans typically appears first, peaks during the acute infection period and is followed by a decline; this limitation, which was due to the lack of available anti-tree shrew IgM antibodies, should be addressed in future studies. Because secondary antibodies specific to tree shrews were not commercially available and the ELISA kits used in this study were developed for use with human serum, we commissioned Sangon Biotech company to synthesize a new secondary antibody and used it instead of the secondary antibody provided with the ELISA kits. The combination of a specific antibody with an ELISA kit has been applied in previous research [24]; the secondary antibody used in this study was shown to be specific and can be used in future research involving tree shrews.

We euthanized tree shrews after different observation periods ranging from 3 to 21 weeks; these time points may correspond to different stages of infection.Tree shrews that were infected by EBV for a long time were found to be in a state of latent EBV infection. The appearance of these tree shrews was normal, without obvious weakness; their condition may be similar to that of humans that have been shown to be long-term EBV carriers without any clinical manifestations. In the histopathological investigation, EBERs and LMP1- and EBNA2-positive cells were detected in the spleen. These cells were in the germinal centre, where viral and local tissue factors could mediate their effects and expansion [49].Consistent with a previous study showing that EBV infects B cells and epithelial cells, these cells appeared to be B lymphocytes; however,it is difficult to clarify whether the lymphocytes were $\mathrm{B}$ cells or $\mathrm{T}$ cells because of the absence of tree-shrew-specific reagents for the examination. EBER-and/or LMP1-positive cells were detected in the mesenteric lymph nodes of three tree shrews, and Western blotting detected EBNA1 in the spleens of Ts2, Ts3, Ts9 and Ts10. Furthermore, the detection of EBNA2 expression in the spleens of Ts10 but not in PBMCs or inliveror lung tissue again demonstrates that lymphoid tissue is the target site of EBV proliferation, consistent with the results described previously [50]. The EBV-related gene and protein expression suggest that tree shrews were in the latency I and II infection stages. However, the immune systems of the tree shrews without EBV-marker-positive cells in their tissues may have responded strongly to EBV and eliminated the virus from theanimals. Further characterization of the factors that help eliminate EBV could help in the treatment and prevention of EBVrelated diseases. EBV can enter human epithelial cells via receptors [51, 52], through direct contact between cells $[53,54]$, by involvement of the virus envelope protein $[55,56]$, and through assistance mediated by cytokines [57]. However, in this study, we did not detect EBVpositive signals in the nasopharynges or lungs of the infected animals. The use of EBV intravenous inoculation may have prevented EBV from entering the lymphoid tissue,nasopharynx or oropharynx. Future studies should address whether EBV can enter the epithelial cells of tree shrews, whether the mechanism of EBV entry into the nasopharynx isthe same as that in humans, and the exact route of entry. The lung is not susceptible to EBV, whichmay explain why we failed to detect EBV-positive signals in the lung. These results further confirmed that the target cells of EBV are lymphocytes andthat the primary organ infected by EBV is the spleen. These results are consistent with those obtained in previousstudies.

\section{Conclusion}

In this study, we preliminarily confirmed that EBV caninfect treeshrews after intravenous injection at a rate of $80 \%$. This work establishes a foundation for the construction of an animal model of EBV infection in the future. Because of the similarity of tree shrews to primates, the tree shrew model of EBV offers some advantages for studying the infection and pathogenic mechanism of EBV and for the development of medicines and vaccines.

\section{Methods}

Animals

Thirteen adult (1-1.5 years of age) male and female tree shrews with body weights ranging from 120 to $160 \mathrm{~g}$ were obtained from the Experimental Animal Center of 
Kunming Medical University (Kunming, China). All animals were reared artificially since birth, housed under controlled environmental conditions with a $12 \mathrm{~h}$ light/ dark photoperiod at the Laboratory Animal Center of Guangxi Medical University, and monitored by veterinarians. They were fed a complete formula food and provided water adlibitum. The experiment was begun after the tree shrews had undergone an adaptation period of at least one week.

\section{Preparation of EBV and inoculation of tree shrews}

B95-8 cells (marmoset EBV-immortalized B-cell line) were cultured inRPMI1640 medium (Gibco, USA) supplemented with $10 \%$ foetal bovine serum (Gibco) and $1 \times$ antibiotics $(100 \mathrm{kU} / \mathrm{l}$ penicillin, $100 \mathrm{mg} / \mathrm{l}$ streptomycin, both from (Solarbio, Beijing, China)at $37^{\circ} \mathrm{C}$ and $5 \% \mathrm{CO}_{2}$ in a humidified incubator. Growth medium was added to a sufficient volume when the cell density reached approximately $5 \times 10^{6} \mathrm{cells} / \mathrm{ml}$, and the cells were then cultured for 14 days. The cultures werefrozen at $-80^{\circ} \mathrm{Cand}$ thawed 3 times in a water bath at $37{ }^{\circ} \mathrm{C}$. Then, the supernatants were filtered using $0.45-\mu \mathrm{m}$ filters to eliminate cells and centrifuged at $16,000 \mathrm{~g}$ at $4^{\circ}$ Cfor $90 \mathrm{~min}$ to remove cell debris using a high-speed refrigerated centrifuge(Beckman Coulter,USA). After centrifugation, the pellets were resuspended in fresh RPMI 1640 medium and stored at $-80{ }^{\circ} \mathrm{C}$ until tree shrew infection, as previously described.

\section{Inoculation of tree shrews with EBV}

Ten tree shrews were inoculated with EBV by intravenous injection of $500 \mu \mathrm{l}$ of the viral solution described previously. The EBV copy number in the inoculums was approximately $3.9 \times 10^{8}$ copies per animal as confirmed by real-time quantitative PCR(qPCR).The infectivity of the virus in the viral solution was assessed by its ability to successfully immortalize human PBMCs in vitro [25, 58]. The10 tree shrews inoculated with EBV were designated Ts1-Ts10. The week of viral inoculation was defined as "week 0."As negative controls, three tree shrews (Ts11Ts13) were inoculated with fresh RPMI 1640 medium containing 10\% FBS using the same procedure.

\section{Collection of PBMCs and serum from the blood of tree shrews}

Approximately $1.5 \mathrm{ml}$ of blood was collected at regular intervals from the tree shrews in anticoagulative tubes containing EDTA.2Na(1 ml) and in sterile centrifuge tubes without anticoagulant $(0.5 \mathrm{ml})$ from the femoral artery or vein. The anticoagulant blood was used to isolate peripheral blood mononuclear cells(PBMCs) using a Peripheral Blood Mononuclear Cell Separation Kit for Mice(Solarbio,Beijing, China); the blood collected in the other tubes was centrifuged at $3500 \mathrm{rpm}$ at $4^{\circ} \mathrm{Cin}$ a
centrifuge(Eppendorf,Germany) and the serum was carefully isolated. The serum samples were stored at $-20{ }^{\circ} \mathrm{C}$.

\section{Quantitative real-time PCR (qPCR) for the detection of EBV copy number}

DNA was extracted from the initial inocula and from tree shrew PBMCs using the QIAamp DNA Mini Kit(Qiagen,Hilden, Germany)according to the manufacturer's protocol. The EBV viral load in the original inocula and in the PBMCs was estimated using $\mathrm{qPCR}$ targeting the EBV BamHIW region. DNA from the Namalwa cell line (a Burkitt lymphoma cell line containing two copies of EBV), which was purchased from the Shanghai Institute for Biological Sciences, Chinese Academy of Sciences Institute of Cell Resource Center (Shanghai,China), was used as a standard as previously reported [59]. The culture conditions for the Namalwa cells and the DNA extraction methodology were as previously described. The quantity and purity of the extracted DNA were determined using a NanoDrop2000 instrument (Thermo Fisher Scientific,USA). Next, qPCR was performed on $2 \mu \mathrm{l}$ of template DNA in a total reaction volume of $20 \mu \mathrm{l}$ with Premix ExTaq ${ }^{\mathrm{TM}}$ (Probe qPCR) (Takara, Japan) using the described primers and a fluorogenic probe [59] synthesized by Takara Biotechnology Co. (Japan). All samples were analysed in duplicate in a 40-cycle reaction on an Applied Biosystems Step One Plus real-time PCR machine. All experiments were repeated 3 times independently, and the mean value obtained in the 3 experiments was considered the copy number of the samples.

\section{Reverse transcription polymerase chain reaction (RT-PCR) for the detection of EBV-related gene expression in PBMCs}

Total RNA was extracted from tree shrew PBMCs with the RNAsimple Total RNA Kit (Tiangen, Beijing, China) according to the manufacturer's protocol and quantified using a NanoDrop2000 instrument. Then, 500 ng of RNA was reverse transcribed to cDNA using the EasyScript One-Step gDNA Removal and cDNA Synthesis SuperMix (TransGen Biotech, Beijing, China).RT-PCR was performed with a PCR Mix(Invitrogen, USA) according to the manufacturer's protocol. The expression of BZLF1,LMP1,EBNA1,EBNA2 and EA was determined by RT-PCR using the primers,including 4 primers we designed for RT-PCR, as follows:BZLF1: 5'-GCG GAC AAA AAT CAG GCG TT-3' and 5'-GAA AAT GCC GGG CCA AGT TT-3'; LMP1:5' -AAT TTG CAC GGA CAG GCA TT-3' and 5' ${ }^{\prime}$ AAG GCC AAA AGC TGC CAG AT-3'; EBNA2: 5'-AAC TCC TGG CCC ATC CAA TG-3' and 5'-GGA GGG GCG AGG TCT TTT AC-3'; EA: 5'-AAC GAG CAG ATG ATT GGG CA-3' and $5^{\prime}$-CGT GGT GAC GTA GAG ATC CG-3' and 1 
primers previously reported [60]: EBNA1: 5 '-GTC ATC ATC ATC CGG GTC TC-3' and 5'-TTC GGG TTG GAA CCT CCT TG-3'. The "housekeeping gene" $\beta$-actin was amplified as an internal control using the primers previously described [61], and cDNA from B95-8 cells was used as a positive control.

\section{Enzyme-linked immunosorbent assay (ELISA) for the determination of EBV antibodies in tree shrew serum} EBV antibodies in tree shrew serum were measured using an enzyme-linked immunosorbent assay (ELISA).The anti-EBV capsid antigen(VCA) IgG,EBV nuclear antigen (EBNA) IgG, and early antigen (EA) IgG were measured with the Epstein-Barr virus VCA IgG ELISA Kit(Abnova,Taiwan, China),a human Epstein-Barr virus nuclear antigen (EBNA1) antibody (IgG) ELISA kit (CUSABIO, Wuhan, China), and a human Epstein-Barr virus early antigen (EBEA) antibody (IgG) ELISA kit (CUSABIO).Tree shrew serum diluted 1:10 with dilution buffer was placed into each plate, and bound antibodies were subsequently detected using rabbit anti-tree shrew IgGsecondary antibody synthesized by Sangon Biotech Co.,Ltd. (Shanghai, China). The antibody was diluted 1:3000 in5\% defatted milk. After incubation at $37^{\circ} \mathrm{C}$ for $45 \mathrm{~min}$ or $30 \mathrm{~min}$,tetramethylbenzidine (TMB) solution or a mixture reagent of colour A and B was added, and colour was allowed to develop for $10 \mathrm{~min}$ in the dark.Then,the stop solution was added, and the absorbance of each well was measured at $450 \mathrm{~nm}$.

\section{EBER-in situ hybridization(ISH) for the detection of EBV in tree shrew tissues}

We detected EBER1 and EBER2 in tissues according to the EBER in situ hybridization protocol [62] and the EBER1、EBER2 probe sequences [63, 64] as previously described. Highly sensitive digoxigenin-labelled oligonucleotide probes were synthesized by Bioneer (Korea).Briefly, the process was performed on $5-\mu \mathrm{m}$ sections of formalin-fixed,paraffin-embedded tissue sections of the spleens,livers,mesenteric lymph nodes,lungs, and nasopharynges of autopsied tree shrews. Sections of EBV-infected B95-8 cells were used as a positive control.Pre-hybridization was performed for $2-4 \quad \mathrm{~h}$ to reduce nonspecific binding prior to hybridization overnight with a mixture of EBER-1 and EBER-2 probes. The hybridized probes were subsequently detected using the 2 -step plus ${ }^{\circ}$ Poly-HRP AntiMouse/Rabbit IgG Detection System from Zhongshan Goldenbridge Biotech (Beijing, China). Diaminobenzidinetetrahydrochloride (DAB) (ZhongshanGoldenbridge Biotech) was used as the chromogen. Other reagents, including proteaseK,preliminary hybridization solutio$\mathrm{n}$, and oligonucleotide probe diluent, were provided by Boster Biotech(Wuhan, China).

\section{Pathological and immunohistochemical detection in tree shrews}

Eleven of the 13 tree shrews were autopsied. Tissues, including the spleen, liver, mesenteric lymph nodes, lung and nasopharynx, were examined by haematoxylin and eosin (H\&E) and immunohistochemistry for detecting the expression of EBV LMP1 and EBNA2 was performed on 5- $\mu \mathrm{m}$ paraffin-embedded tissue sections using mouse anti-LMP1 monoclonal antibody [CS 1-4] (Abcam, UK) and mouse anti-EBNA2 monoclonal antibody [PE2] (Abcam), both at 1/100 dilution, according to the protocol provided with the 2-step plus Poly-HRP AntiMouse/Rabbit IgG Detection System and DAB detection system.

\section{Western blotting analysis of EBV gene expression in tree shrews}

Proteins were extracted from spleen and liver tissues with $1 \times$ RIPA buffer (radioimmune precipitation buffer containing protease inhibitor cocktail set I, Beyotime, Shanghai, China), and the protein concentration was determined using an Enhanced BCA Protein Assay Kit (Beyotime). Western blotting analysis of EBV gene expression was performed using $80 \mu \mathrm{g}$ of protein from the spleen and liver tissues of tree shrews, and GAPDH was used as an internal control. The primary antibodies used were mouse anti-EBNA1 monoclonal antibody (0211)(Thermo Fisher Scientific, USA) and mouse antiGAPDH antibody at dilutions of $1 / 50$ and $1 / 10000$, respectively. The signals were detected using IRDye ${ }^{\circ}$ 680RD goat-anti-mouse IgG $(\mathrm{H}+\mathrm{L})$ antibody (Licor, USA) at a dilution of $1 / 10000$ and an Odyssey dualcolour infrared fluorescence imaging detection system (Licor).

\section{Abbreviations}

ADV: Adenovirus; BRLF: BamHI R fragment leftward reading frame; BZLF: BamHI Z fragment leftward reading frame; EA: Early antigen; EBERs: EBV non-protein-encoding RNAs; EBNA: EBV nuclear antigen; EBV: Epstein-Barr virus; ELISA: Enzyme-linked immunosorbent assay; HAV: Hepatitis A virus; HBV: Hepatitis B virus; HCV: Hepatitis C virus; HE: Haematoxylin and eosin; HRV: Rotavirus; HSV: Herpes virus; huPBLs: Human peripheral blood Iymphocytes; IHC: Immunohistochemistry; IM: Infectious mononucleosis; ISH: In situ hybridization; LCLs: Lymphoblastoid cell lines; LMP: Latent membrane protein;NK:Natural killer cell; NPC: Nasopharyngeal carcinoma; PBMCs: Peripheral blood mononuclear cells; PTLD: Post-transplant lymphoproliferative disorders; qPCR: Quantitative real-time PCR; RTPCR: Reverse transcription polymerase chain reaction; SCID: Severe combined immunedeficiency; VCA: EBV capsid antigen; WB: Western blotting

\section{Acknowledgements}

We would like to thank the staff of the Laboratory Animal Center of Guangxi Medical University for their help in breeding animals. This work was supported by the Guangxi Medical University Laboratory Animal Center (Guangxi, China).

\section{Funding}

The research was financially supported by the Guangxi Natural Science Foundation project (11-31-03). 


\section{Availability of data and materials}

The datasets generated during and analysed during the current study are available from the corresponding author on reasonable request.

\section{Authors' contributions}

ZW conducted the animal experiments, participated in the study design, performed most of the molecular and pathology studies and drafted the manuscript. AZT conceived of the study, carried out its design and helped to draft the manuscript. $X Y$ participated in study design and helped to draft the manuscript. LD, HW, WX, and YJL helped conduct the RT-PCR, GPCR. JT, MLW, CLQ and HL participated in animal experiments and pathology studies. All authors read and approved the final manuscript.

\section{Ethics approval}

All animal experimental procedures were approved by the institutional animal research ethics committee of Guangxi Medical University, document number 201504030

\section{Consent for publication}

Not applicable.

\section{Competing interests}

The authors declare no competing interests in relation to this manuscript.

\section{Publisher's Note}

Springer Nature remains neutral with regard to jurisdictional claims in published maps and institutional affiliations.

\section{Received: 9 February 2017 Accepted: 25 September 2017}

\section{Published online: 06 October 2017}

\section{References}

1. Sun L, Che K, Zhao Z, Liu S, Xing X, Luo B. Sequence analysis of Epstein-Barr virus (EBV) early genes BARF1 and BHRF1 in NK/T cell lymphoma from Northern China. Virol J. 2015:12:135

2. Balfour HH Jr, Odumade OA, Schmeling DO, Mullan BD, Ed JA, Knight JA, et al. Behavioral, virologic, and immunologic factors associated with acquisition and severity of primary Epstein-Barr virus infection in university students. J Infect Dis. 2013;207(1):80-8.

3. Li H, Liu S, Hu J, Luo X, Li N, MB A, et al. Epstein-Barr virus lytic reactivation regulation and its pathogenic role in carcinogenesis. Int J Biol Sci. 2016; 12(11):1309-18.

4. Thorley-Lawson DA, Babcock GJ. A model for persistent infection with Epstein-Barr virus: the stealth virus of human B cells. Life Sci. 1999;65(14): 1433-53.

5. Babcock GJ, Hochberg D, Thorley-Lawson AD. The expression pattern of Epstein-Barr virus latent genes in vivo is dependent upon the differentiation stage of the infected B cell. Immunity. 2000;13(4):497-506.

6. Sugimoto $M$, Tahara $H$, Ide T, Furuichi $Y$. Steps involved in immortalization and tumorigenesis in human B-lymphoblastoid cell lines transformed by Epstein-Barr virus. Cancer Res. 2004;64(10):3361-4.

7. Kuppers R. B cells under influence: transformation of B cells by Epstein-Barr virus. Nat Rev Immunol. 2003:3(10):801-12.

8. Kelly GL, Milner AE, Baldwin GS, Bell Al, Rickinson AB. Three restricted forms of Epstein-Barr virus latency counteracting apoptosis in c-myc-expressing Burkitt lymphoma cells. Proc Natl Acad Sci U S A. 2006;103(40):14935-40.

9. Cancian L, Bosshard R, Lucchesi W, Karstegl CE, Farrell PJ. C-terminal region of EBNA-2 determines the superior transforming ability of type 1 EpsteinBarr virus by enhanced gene regulation of LMP-1 and CXCR7. PLoS Pathog. 2011;7(7):e1002164.

10. Zhang B, Kracker S, Yasuda T, Casola S, Vanneman M, Homig-Holzel C, et al. Immune surveillance and therapy of lymphomas driven by Epstein-Barr virus protein LMP1 in a mouse model. Cell. 2012;148(4):739-51.

11. Harada S, Kieff E. Epstein-Barr virus nuclear protein LP stimulates EBNA-2 acidic domain-mediated transcriptional activation. J Virol. 1997;71(9):6611-8.

12. Xu FH, Xiong D, Xu YF, Cao SM, Xue WQ, Qin HD, et al. An epidemiological and molecular study of the relationship between smoking, risk of nasopharyngeal carcinoma, and Epstein-Barr virus activation. J Natl Cancer Inst. 2012;104(18):1396-410.
13. Shope T, Dechairo D, Miller G. Malignant lymphoma in cottontop marmosets after inoculation with Epstein-Barr virus. Proc Natl Acad Sci U S A. 1973;70(9):2487-91.

14. Niedobitek G, Agathanggelou A, Finerty S, Tierney R, Watkins P, Jones EL, et al. Latent Epstein-Barr virus infection in cottontop tamarins. A possible model for Epstein-Barr virus infection in humans. Am J Pathol. 1994;145(4): 969-78.

15. Cleary ML, Epstein MA, Finerty S, Dorfman RF, Bornkamm GW, Kirkwood JK, et al. Individual tumors of multifocal EB virus-induced malignant lymphomas in tamarins arise from different B-cell clones. Science. 1985; 228(4700):722-4

16. Mosier DE, Gulizia RJ, Baird SM, Wilson DB. Transfer of a functional human immune system to mice with severe combined immunodeficiency. Nature. 1988;335(6187):256-9.

17. Molinie V, Pouchot J, Navratil E, Aubert F, Vinceneux P, Barge J. Primary Epstein-Barr virus-related non-Hodgkin's lymphoma of the pleural cavity following long-standing tuberculous empyema. Arch Pathol Lab Med. 1996; 120(3):288-91.

18. Chijioke O, Muller A, Feederle R, Barros MH, Krieg C, Emmel V, et al. Human natural killer cells prevent infectious mononucleosis features by targeting Iytic Epstein-Barr virus infection. Cell Rep. 2013;5(6):1489-98.

19. Hartlage AS, Liu T, Patton JT, Garman SL, Zhang X, Kurt H, et al. The EpsteinBarr Virus Lytic Protein BZLF1 as a Candidate Target Antigen for Vaccine Development. Cancer Immunol Res. 2015;3(7):787-94.

20. Wilson JB, Bell $J$ L, Levine AJ. Expression of Epstein-Barr virus nuclear antigen-1 induces B cell neoplasia in transgenic mice. EMBO J. 1996;15(12) 3117-26.

21. Hannigan A, Qureshi AM, Nixon C, Tsimbouri PM, Jones S, Philbey AW, et al. Lymphocyte deficiency limits Epstein-Barr virus latent membrane protein 1 induced chronic inflammation and carcinogenic pathology in vivo. Mol Cancer. 2011;10(1):11.

22. Kulwichit W, Edwards RH, Davenport EM, Baskar JF, Godfrey V, Raab-Traub N. Expression of the Epstein-Barr virus latent membrane protein 1 induces $B$ cell lymphoma in transgenic mice. Proc Natl Acad Sci U S A. 1998;95(20): 11963-8.

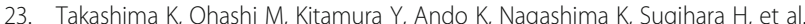
A new animal model for primary and persistent Epstein-Barr virus infection: human EBV-infected rabbit characteristics determined using sequential imaging and pathological analysis. J Med Virol. 2008;80(3):455-66.

24. Okuno K, Takashima K, Kanai K, Ohashi M, Hyuga R, Sugihara H, et al. Epstein-Barr virus can infect rabbits by the intranasal or peroral route: an animal model for natural primary EBV infection in humans. J Med Virol. 2010:82(6):977-86

25. Khan G, Ahmed W, Philip PS, Ali MH, Adem A. Healthy rabbits are susceptible to Epstein-Barr virus infection and infected cells proliferate in immunosuppressed animals. Virol J. 2015;12:28.

26. Kanai K, Kato K, Sano H, Nagata K, Okuno K, Kuwamoto S, et al. In vitro Epstein-Barr virus infection model of rabbit lymphocytes from peripheral blood or spleen. Intervirology. 2011;54(1):17-24.

27. Yang C, Ruan P, Ou C, Su J, Cao J, Luo C, et al. Chronic hepatitis B virus infection and occurrence of hepatocellular carcinoma in tree shrews (Tupaia belangeri chinensis). Virol J. 2015;12:26.

28. Fan Y, Huang ZY, Cao CC, Chen CS, Chen YX, Fan DD, et al. Genome of the Chinese tree shrew. Nat Commun. 2013;4:1426.

29. Li R, Xu W, Wang Z, Liang B, Wu JR, Zeng R. Proteomic characteristics of the liver and skeletal muscle in the Chinese tree shrew (Tupaia belangeri chinensis). Protein Cell. 2012:3(9):691-700.

30. Zhan MY, Liu CB, Li CM, Zhang WY, Zhu C, Pang QF, et al. A preliminary study of hepatitis A virus in Chinese tupaia (author's transl). Zhongguo $Y$ Xue Ke Xue Yuan Xue Bao. 1981:3(3):148-52.

31. Wang Q, Schwarzenberger P, Yang F, Zhang J, Su J, Yang C, et al. Experimental chronic hepatitis B infection of neonatal tree shrews (Tupaia belangeri chinensis): a model to study molecular causes for susceptibility and disease progression to chronic hepatitis in humans. Virol J. 2012:9:170.

32. Amako Y, Tsukiyama-Kohara K, Katsume A, Hirata Y, Sekiguchi S, Tobita Y, et al. Pathogenesis of hepatitis C virus infection in Tupaia belangeri. J Virol. 2010;84(1):303-11.

33. Pang QF, Liu JC, Wan XB, Qiu FX, Xu AY. Experimental infection of adult Tupaia belangeri yunalis with human rotavirus. Chin Med J. 1983;96(2):85-94.

34. Schoeb TR, DaRif CA. Adenoviral infection in infant tree shrews. J Am Vet Med Assoc. 1984;185(11):1363-6. 
35. Li L, Li Z, Wang E, Yang R, Xiao Y, Han H, et al. Herpes Simplex Virus 1 Infection of Tree Shrews Differs from That of Mice in the Severity of Acute Infection and Viral Transcription in the Peripheral Nervous System. J Virol. 2015;90(2):790-804.

36. Li SA, Lee WH, Zhang Y. Two bacterial infection models in tree shrew for evaluating the efficacy of antimicrobial agents. Dongwuxue Yanjiu. 2012; 33(1):1-6.

37. McBrien NA, Arumugam B, Metlapally S. The effect of daily transient +4 D positive lens wear on the inhibition of myopia in the tree shrew. Invest Ophthalmol Vis Sci. 2012;53(3):1593-601.

38. Wu X, Chang Q, Zhang Y, Zou X, Chen L, Zhang L, et al. Relationships between body weight, fasting blood glucose concentration, sex and age in tree shrews (Tupaia belangeri chinensis). J Anim Physiol Anim Nutr (Berl). 2013;97(6):1179-88.

39. Okano M, Gross TG. Epstein-Barr virus-associated hemophagocytic syndrome and fatal infectious mononucleosis. Am J Hematol. 1996;53(2): 111-5.

40. Klein $E$, Kis LL, Klein G. Epstein-Barr virus infection in humans: from harmless to life endangering virus-lymphocyte interactions. Oncogene. 2007;26(9): 1297-305.

41. MacArthur GJ, Wilson AD, Birchall MA, Morgan AJ. Primary CD4+ T-cell responses provide both helper and cytotoxic functions during Epstein-Barr virus infection and transformation of fetal cord blood B cells. J Virol. 2007; 81(9):4766-75

42. Hadinoto V, Shapiro M, Greenough TC, Sullivan JL, Luzuriaga K, ThorleyLawson DA. On the dynamics of acute EBV infection and the pathogenesis of infectious mononucleosis. Blood. 2008;111(3):1420-7.

43. Zhang Y, Ohyashiki JH, Takaku T, Shimizu N, Ohyashiki K. Transcriptional profiling of Epstein-Barr virus (EBV) genes and host cellular genes in nasal NK/T-cell lymphoma and chronic active EBV infection. Br J Cancer. 2006; 94(4):599-608

44. Bauer G. Simplicity through complexity: immunoblot with recombinant antigens as the new gold standard in Epstein-Barr virus serology. Clin Lab. 2001:47(5-6):223-30

45. Zuo L, Yu H, Liu L, Tang Y, Wu H, Yang J, et al. The copy number of EpsteinBarr virus latent genome correlates with the oncogenicity by the activation level of LMP1 and NF-kappaB. Oncotarget. 2015;6(38):41033-44.

46. Tsurumi T, Fujita M, Kudoh A. Latent and lytic Epstein-Barr virus replication strategies. Rev Med Virol. 2005;15(1):3-15.

47. Schillinger M, Kampmann M, Henninger K, Murray G, Hanselmann I,Bauer G. Variability of humoral immune response to acute Epstein-Barr virus (EBV) infection: Evaluation of the significance of serological markers.

48. Henle W, Henle G, Andersson J, Ernberg I, Klein G, Horwitz CA, et al. Antibody responses to Epstein-Barr virus-determined nuclear antigen (EBNA)-1 and EBNA-2 in acute and chronic Epstein-Barr virus infection. Proc Natl Acad Sci U S A. 1987;84(2):570-4.

49. Araujo I, Foss HD, Hummel M, Anagnostopoulos I, Barbosa HS, Bittencourt $A$, et al. Frequent expansion of Epstein-Barr virus (EBV) infected cells in germinal centres of tonsils from an area with a high incidence of EBVassociated lymphoma. J Pathol. 1999;187(3):326-30.

50. Kurth J, Hansmann ML, Rajewsky K, Kuppers R. Epstein-Barr virus-infected B cells expanding in germinal centers of infectious mononucleosis patients do not participate in the germinal center reaction. Proc Natl Acad Sci U S A. 2003;100(8):4730-5.

51. Dittmer DP, Hilscher CJ, Gulley ML, Yang EV, Chen M, Glaser R. Multiple pathways for Epstein-Barr virus episome loss from nasopharyngeal carcinoma. Int J Cancer. 2008;123(9):2105-12.

52. Turk SM, Jiang R, Chesnokova LS, Hutt-Fletcher LM. Antibodies to gp350/ 220 enhance the ability of Epstein-Barr virus to infect epithelial cells. J Virol. 2006;80(19):9628-33.

53. Shannon-Lowe C, Rowe M. Epstein-Barr virus infection of polarized epithelial cells via the basolateral surface by memory B cell-mediated transfer infection. PLoS Pathog. 2011;7(5):e1001338.

54. Bornkamm GW, Behrends U, Mautner J. The infectious kiss: newly infected B cells deliver Epstein-Barr virus to epithelial cells. Proc Natl Acad Sci U S A. 2006;103(19):7201-2.

55. Xiao J, Palefsky JM, Herrera R, Tugizov SM. Characterization of the EpsteinBarr virus glycoprotein BMRF-2. Virology. 2007;359(2):382-96.

56. Kirschner AN, Sorem J, Longnecker R, Jardetzky TS. Structure of Epstein-Barr virus glycoprotein 42 suggests a mechanism for triggering receptoractivated virus entry. Structure. 2009;17(2):223-33.
57. Jin W, Li C, Du T, Hu K, Huang X, Hu Q. DC-SIGN plays a stronger role than DCIR in mediating HIV-1 capture and transfer. Virology. 2014;458-459:83-92.

58. Hui-Yuen J, McAllister S, Koganti S, Hill E, Bhaduri-McIntosh S. Establishment of Epstein-Barr virus growth-transformed lymphoblastoid cell lines. J Vis Exp. 2011;57

59. Ryan JL, Fan H, Glaser SL, Schichman SA, Raab-Traub N, Gulley ML. EpsteinBarr virus quantitation by real-time PCR targeting multiple gene segments: a novel approach to screen for the virus in paraffin-embedded tissue and plasma. J Mol Diagn. 2004;6(4):378-85.

60. Babcock GJ, Thorley-Lawson DA. Tonsillar memory B cells, latently infected with Epstein-Barr virus, express the restricted pattern of latent genes previously found only in Epstein-Barr virus-associated tumors. Proc Natl Acad Sci U S A. 2000;97(22):12250-5.

61. Yu D, Xu L, Liu XH, Fan Y, Lu LB, Yao YG. Diverse interleukin-7 mRNA transcripts in Chinese tree shrew (Tupaia belangeri chinensis). PLoS One. 2014;9(6):e99859.

62. Khan G, Coates PJ, Kangro HO, Slavin G. Epstein Barr virus (EBV) encoded small RNAs: targets for detection by in situ hybridisation with oligonucleotide probes. J Clin Pathol. 1992;45(7):616-20.

63. Chang $K L$, Chen YY, Shibata D, Weiss LM. Description of an in situ hybridization methodology for detection of Epstein-Barr virus RNA in paraffin-embedded tissues, with a survey of normal and neoplastic tissues. Diagn Mol Pathol. 1992;1(4):246-55.

64. Khan G. Screening for Epstein-Barr virus in Hodgkin's lymphoma. Methods Mol Biol. 2009;511:311-22.

\section{Submit your next manuscript to BioMed Central and we will help you at every step:}

- We accept pre-submission inquiries

- Our selector tool helps you to find the most relevant journal

- We provide round the clock customer support

- Convenient online submission

- Thorough peer review

- Inclusion in PubMed and all major indexing services

- Maximum visibility for your research

Submit your manuscript at www.biomedcentral.com/submit

) Biomed Central 